\title{
DISTRIBUTION AND DIVERSITY OF FUSARIUM SPECIES ASSOCIATED WITH GRASSES IN TEN STATES THROUGHOUT PENINSULAR MALAYSIA
}

\author{
NUR AIN IZZATI, M.Z..$^{1,2^{*}}$, SITI NORDAHLIAWATE, M.S., ${ }^{2,3}$, NOR AZLIZA, I². \\ and SALLEH, $\mathrm{B}^{2}$. \\ ${ }^{1}$ Department of Biology, Faculty of Science, Universiti Putra Malaysia, 43400 Serdang, \\ Selangor, Malaysia \\ ${ }^{2}$ School of Biological Sciences, Universiti Sains Malaysia, 11800 Minden, Pulau Pinang, Malaysia \\ ${ }^{3}$ Department of Agrotechnology, Faculty of Agrotechnology and Food Science, Universiti Malaysia \\ Terengganu, 21030 Mengabang Telipot, Kuala Terengganu, Malaysia
}

\begin{abstract}
Fusarium is one of the important genera associated with grasses as saprophytes, endophytes and pathogens. A study was carried out on distribution and diversity of Fusarium species associated with two groups of grasses in 10 states throughout Peninsular Malaysia i.e. agricultural grasses (Oryza sativa and Saccharum officinarum) and non-agricultural grasses (Axonopus compressus, Centhotheca lappacea, Chloris barbata, Crysopogon aciculatus, Cyanadon dactylon, Dactyloctenium aegyptium, Digitaria ciliaris, Echinochloa colona, Eleusine indica, Eragrostis amabilis, Eragrostis malayana, Eragrostis uniloides, Ischaemum magnum, Panicum brevifolium, Panicum millaneum, Panicum repens, Paspalum commersonii, Paspalum conjugatum, Paspalum orbiculare, Pennisetum purpureum, Sacciolepis indica, Sporobolus diander and Sporobolus indicus). A total of 474 isolates were singlespored and identified by morphological characteristics. F. semitectum was frequently isolated (23.6\%), followed by F. sacchari and F. fujikuroi with $15.4 \%$ and $14.6 \%$, respectively. The other nine species were F. solani (10.3\%), F. proliferatum (8.9\%), F. oxysporum (7.4\%), F. subglutinans (6.5\%), F. equiseti (5.5\%), F. verticillioides (3.4\%), F. compactum (2.5\%), F. chlamydosporum (1.1\%) and F. longipes $(0.8 \%)$. Based on the Shannon-Weiner Index, F. solani was the highest $\left(\mathrm{H}^{\prime}=2.62\right)$ isolated from grasses. Species of Fusarium from O. sativa were widely diverse with 11 species, followed by non-agricultural grasses with nine species and $S$. officinarum with only six species. This is the first report on diversity of Fusarium associated with grasses in Malaysia.
\end{abstract}

Keywords: Oryza sativa, Saccharum officinarum, non-agricultural grass, Fusarium species, diversity and Gramineae

\section{INTRODUCTION}

Fusarium species are well-known as soil borne fungi and widely distributed and could be associated with any parts of various plants from the deepest roots to the

\footnotetext{
$\overline{\text { *Corresponding author : izzati@ }}$ science.upm.edu.my
} 
highest flowers, plant debris and other organic substrates. It can exist as free-living saprophytic, parasitic, pathogenic or toxigenic fungi (Booth 1971; Nelson et al. 1983; Burgess et al. 1994). Most of the Fusarium species are found in fertile, cultivated and rangeland soils but are relatively uncommon in forest soils (Burgess et al. 1994). Several species in this genus have been reported as serious plant pathogens causing various diseases such as crown rot, head blight and scab on grains, vascular wilts on a wide range of horticultural crops, root rots, cankers and other important diseases such as pokkah boeng on sugarcane and bakanae disease on rice (Nelson et al. 1983; Webster\& Gunnell 1992; Leslie \& Summerell 2006).

The family Gramineae consists of two main groups i.e. high; hard-stemmed grasses e.g. bamboos and sugarcane (Saccharum officinarum), and herbaceous grasses that include cereals bearing grain e.g. maize (Zea mays), rice (Oryza sativa) and sorghum (Sorghum bicolor) (Wycherley \& Mohd Yusof 1974). Other than economically important crops, true grasses could also be one of the suitable hosts for Fusarium species.

In Malaysia as well as in other developed countries, the information on diversity of Fusarium associated with plants under family Gramineae are limited. Thus, this study was conducted to elucidate the distribution and diversity of Fusarium species associated with selected grasses throughout Peninsular Malaysia.

\section{MATERIALS AND METHOD}

\section{Identification of the grasses}

In this study, rice (O. sativa), sugarcane ( $S$. officinarum) and 25 non-agricultural grasses i.e. Axonopus compressus (Broadleaf carpet grass), Centhotheca lappacea, Chloris barbata (Swollen finger grass), Crysopogon aciculatus, Cyanadon dactylon (Bermuda grass), Dactyloctenium aegyptium (Durban crowfoot grass), Digitaria ciliaris (Henry's crab grass), Echinochloa colona (Jungle rice), Eleusine indica (Goose grass), Eragrostis amabilis (Japanese love grass), Eragrostis malayana, Eragrostis uniloides, Ischaemum magnum, Panicum brevifolium, Panicum millaneum, Panicum repens (Torpedo grass), Paspalum vaginatum (Seashore paspalum), Paspalum conjugatum (Hilo grass), Paspalum orbiculare (Rice grass paspalum), Pennisetum purpureum (Elephant grass), Sacciolepis indica (Glenwood grass), Sporobolus diander (Tussock Dropseed) and Sporobolus indicus (Smut grass) were collected throughout 10 states of Peninsular Malaysia (Johor, Kedah, Kelantan, Melaka, Pahang, Perak, Perlis, Pulau Pinang, Selangor and Terengganu). The grasses were identified into species level based on morphological characteristics following Gilliland et al. (1971) and Harada et al. (1996).

\section{Sampling and Isolation of Fusarium isolates}

Sampling was done in various areas within Peninsular Malaysia from 2004 until 2006 and part of the leaves and roots were taken. The samples were maintained in a cool dry state during transit to minimize the growth of saprophytic fungi and bacteria. The technique used was indirectly that involved plating plant tissue segments on agar media. First, samples were surface-sterilized with $0.5 \%$ sodium hypochlorite $(\mathrm{NaOCl})$, then washed three times of sterile water and placed on peptone 
pentachloronitrobenzene agar (PPA) (Nash \& Snyder 1964). The cultures were incubated under the standard growth conditions at room temperature for 7 days and then purified by employing the single-spore isolation technique (Burgess et al. 1994) and incubated at standard incubation conditions (Salleh \& Sulaiman 1984). Single conidia cultures were plated onto potato dextrose agar (PDA) and carnation leaf agar (CLA) for further species delimitation. The pure cultures were used and maintained on water agar (WA) (Burgess \& Liddell 1983) as a short-term working cultures, and preserved in $15 \%$ sterile glycerol at $-80^{\circ} \mathrm{C}$ on a sterile filter papers.

\section{Identification of Fusarium species}

Colony features and pigmentations were recorded after single-spored isolates were cultured on PDA for 7 days. The Methuen handbook of colour chart (Kornerup \& Wancher 1978) was used as a reference for describing the pigmentations. Fusarium isolates were transferred onto CLA plates (Fisher et al. 1982) and incubated for 10 day under the standard growth conditions. The morphological characteristics were observed from slide by using a light microscope (Olympus model BX-50F4) and photographed by using a camera (JVC model KY-F55BE) with an image analyzer-SIS programme. The identification of Fusarium species were carried out based on the taxonomic guidelines by Booth (1971), Burgess and Liddell (1983), Nelson et al. (1983), Burgess et al. (1994), Nirenberg and O'Donnell (1998) and Leslie and Summerell (2006).

\section{Measurement of Species Diversity}

All the Fusarium species that had been verified where then calculated by using the Shannon-Weiner Index (Spellerberg 2008) for species diversity within the grasses family as formula below:

$$
H^{\prime}=-\sum_{i=1}^{s} p_{i} \ln p_{i}
$$

where: $\sum$ refers to "the sum of"

there are $s$ species in the community

$p_{\mathrm{i}}=$ is the relative abundance (proportion) of the ispecies in the community

$\ln =$ natural $\log$

\section{RESULTS AND DISCUSSION}

A total of 474 isolates of Fusarium were isolated, singled-spored and identified from parts of grass samples collected during sampling periods from year 2004 - 2006. As can be derived in Figure 1 and Table 1, 12 species of Fusarium were successfully isolated, and were belonged to six sections i.e. section Arthrosporiella (F. semitectum), section Elegans (F. oxysporum), section Gibbosum and their allied (F. compactum, F. equiseti and F. longipes), section Liseola and their allied (F. fujikuroi, F. proliferatum, $F$. sacchari, F. subglutinans, and F. verticillioides), section Martiella and Ventricosum (F. solani), and section Sporothrichiella (F. Chlamydosporum). 


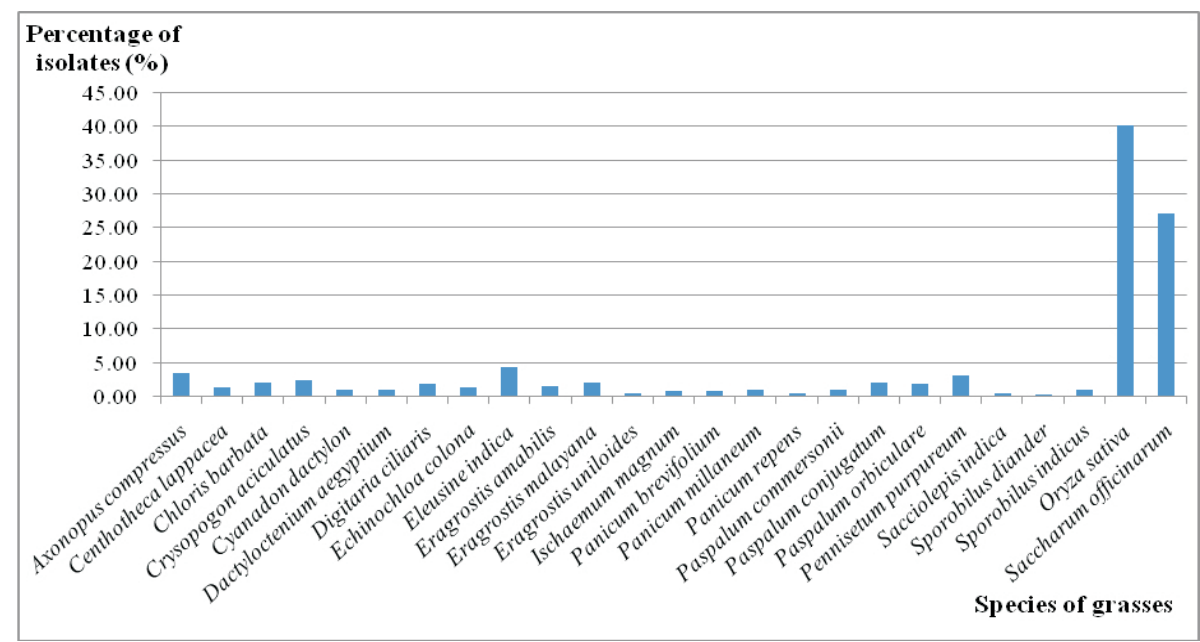

Figure 1. The probability of Fusarium isolates obtained from each species of grasses

Table 1. Frequency of Fusarium isolates belongs to 12 Fusarium species associated with several species of grasses

\begin{tabular}{|c|c|c|c|c|c|c|c|c|c|c|c|c|}
\hline Fusarium species & 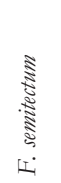 & 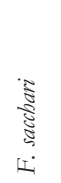 & $\underbrace{3}_{I^{\circ}}$ & 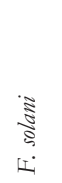 & 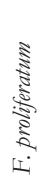 & 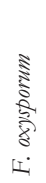 & 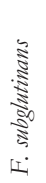 & 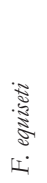 & 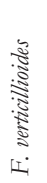 & 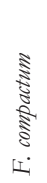 & 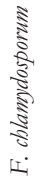 & 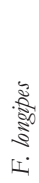 \\
\hline bAxonopus compressus & 3 & - & - & 3 & 1 & - & - & 6 & & 3 & - & - \\
\hline benthotheca lappacea & 1 & - & - & 1 & 1 & 1 & 1 & - & & 1 & - & - \\
\hline${ }^{\mathrm{b}}$ Chloris barbata & 1 & - & - & 3 & - & - & - & 4 & - & 1 & - & - \\
\hline${ }^{\mathrm{b} C r y s o p o g o n}$ aciculatus & 4 & 1 & - & 4 & - & 1 & - & - & - & 1 & - & - \\
\hline byanadon dactylon & 2 & - & - & 1 & - & - & - & - & - & 1 & - & - \\
\hline${ }^{ }$Dactyloctenium aegyptium & 1 & - & - & 3 & - & - & - & - & - & - & - & - \\
\hline b Digitaria ciliaris & 4 & - & - & 2 & - & - & - & 2 & - & - & - & - \\
\hline bEchinochloa colona & 2 & - & - & 1 & 1 & - & 2 & - & - & - & - & - \\
\hline b Eleusine indica & 10 & - & - & 3 & 2 & - & - & 3 & - & - & 2 & - \\
\hline $\mathrm{b}$ Eragrostis amabilis & - & - & - & 4 & - & 1 & - & 1 & - & 1 & - & - \\
\hline $\mathrm{b}$ Eragrostis malayana & 1 & - & - & 2 & 1 & 2 & - & 3 & - & - & - & - \\
\hline $\mathrm{b}$ Eragrostis uniloides & 1 & - & - & - & - & 1 & - & - & - & - & - & - \\
\hline bIschaemum magnum & - & - & - & 1 & - & - & - & - & - & 2 & - & - \\
\hline bPanicum brevifolium & 2 & - & - & - & - & - & 1 & - & - & - & - & - \\
\hline bPanicum millaneum & 2 & - & - & 1 & 1 & - & - & - & - & - & - & - \\
\hline bPanicum repens & - & - & - & - & 1 & 1 & - & - & - & - & - & - \\
\hline bPaspalum commersonii & 2 & - & - & - & - & 1 & 1 & - & - & - & - & - \\
\hline bPaspalum conjugatum & 2 & 3 & - & 2 & - & - & - & 1 & - & 1 & - & - \\
\hline bPaspalum orbiculare & 4 & - & - & 2 & - & 1 & - & - & - & 1 & - & - \\
\hline bPennisetum purpureum & 8 & - & - & 2 & 2 & - & - & 1 & - & - & 1 & - \\
\hline b Sacciolepis indica & 1 & - & - & - & 1 & - & - & - & - & - & - & - \\
\hline bSporobilus diander & 1 & - & - & - & - & - & - & - & - & - & - & - \\
\hline bSporobilus indicus & 3 & - & - & - & - & - & 1 & - & - & - & - & - \\
\hline Oryza sativa & 33 & 11 & 69 & 11 & 13 & 26 & 4 & 1 & 16 & - & 2 & 4 \\
\hline Saccharum officinarum & 24 & 58 & - & 3 & 18 & - & 21 & 4 & & - & - & - \\
\hline Percentage (\%) & 23.6 & 15.4 & 14.6 & 10.3 & 8.9 & 7.4 & 6.5 & 5.5 & 3.4 & 2.5 & 1.1 & 0.8 \\
\hline Total of isolates & 112 & 73 & 69 & 49 & 42 & 35 & 31 & 26 & 16 & 12 & 5 & 4 \\
\hline
\end{tabular}

A total of 474 isolates of Fusarium species

${ }^{b}$ True grasses 
The most dominant species was F. semitectum (112 isolates; $23.6 \%$ ) that belonged to the section Arthrosporiella. This species was the most prevalent species associated with the grasses; being present in $94 \%$ of the grass samples. F. semitectum is cosmopolitan (Nelson et al. 1983); regularly found as secondary invaders in diseased tissues (Summerell et al. 2003) and frequently isolated on aerial plant parts in subtropical and tropical regions (Leslie \& Summerell 2006), commonly isolated from soils (Burgess et al. 1994; Nik Mohd Izham et al. 2005) and from diverse aerial parts of several plants, namely asparagus (Al-Amodi 2006), kangaroo paw (Satou et al. 2001), potatoes (Kim et al. 1995) and some grasses (Nor Azliza et al. 2005). F. semitectum is not considered as an important pathogen although there were reports of this species being associated with several plant diseases such as corky dry rot of melons (Carter 1979) and storage rot of tropical crops (Booth 1971).

The second highest isolates were F. sacchari with 73 isolates $(15.4 \%)$, followed by $F$. fujikuroi with 69 isolates (14.6\%). Both later species were frequently isolated from sugarcane ( $S$. officinarum) and rice (Oryza sativa), respectively. F. sacchari was found in Asia on sugarcane as the cause of pokkah boeng disease (Nirenberg \& O'Donnell 1998; Leslie \& Summerell 2006). F. sacchari has been isolated from sugarcane with pokkah boeng disease (Siti Nordahliawate et al. 2008) and was also isolated from the true grass samples at sugarcane plantations of Padang Terap, Kedah i.e. Eleusine indica (Goose grass) and Dactyloctenium aeygyptium (Durban crowfoot grass). Thus, both collected grasses were assumed to be the secondary hosts for this fungus prior to their invasion into the sugarcane. F. saccharialso has been isolated from sorghum, maize and orchids (Leslie \& Summerell 2006).

F. fujikuroi was also noted as the most dominant species isolated, mainly from the rice. This species has been reported as a causal agent for bakanae disease on rice (Webster \& Gunnell 1992; Nur Ain Izzati et al. 2008). F. verticillioides was reported as a pathogen on maize and can be found worldwide wherever maize is cultivated (Leslie \& Summerell 2006). This species causes epidemics called maize ear rot in Africa, Europe, North and South America, and Asia (Chulze et al. 2000; Danielsen et al. 1998; Desjardins et al. 2000; Kedera et al. 1999; Leslie 1995; Mulè et al. 2004; Munkvold \& Desjardins 1997).

F. solani was also a common species that was isolated from all genera of grasses but the frequency level was less than those of earlier species with 49 isolates $(10.3 \%)$. Meanwhile, F. chlamydosporum and F. longipes were noted as the least frequent species with 5 isolates $(1.1 \%)$ and 4 isolates $(0.8 \%)$, respectively. The other six species, i.e. F. compactum, F. equiseti, F. oxysporum, F. proliferatum, F. subglutinans, and F. verticillioides. F. semitectum and F. solani were unevenly distributed in all 10 states throughout Peninsular Malaysia (Fig. 2). In contrast, F. longipes which is known as cosmopolitan soil inhabitant that has been recovered from many parts of the world, but in this study, this species only recovered in Pahang from O. sativa samples. 


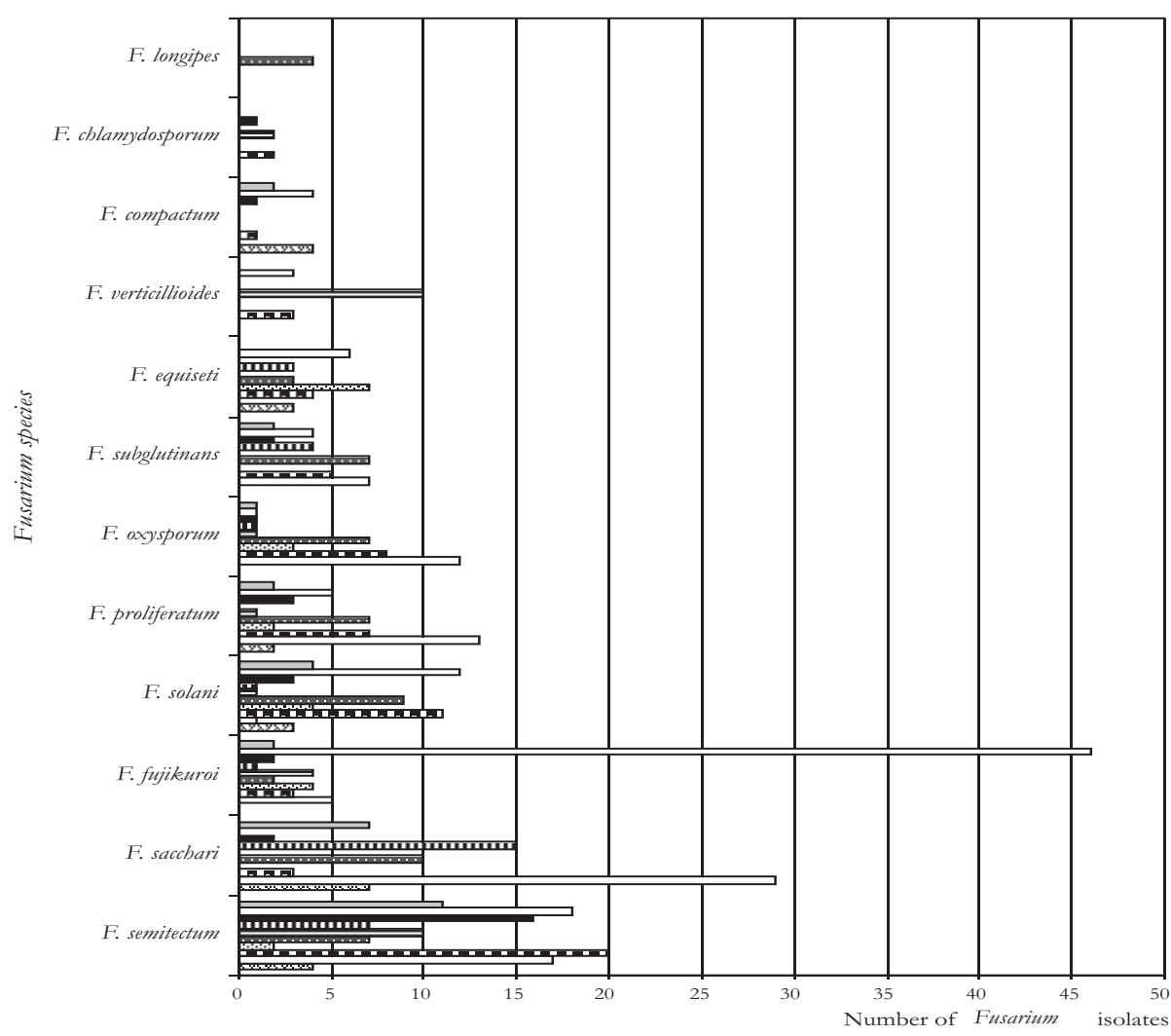

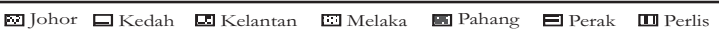

Pulau Pinang

$\square$ Selangor

口Terengganu

Figure 2. Distribution of Fusarium species associated with grasses in Peninsular Malaysia

F. solani is cosmopolitan on a wide-range of substrates (Nelson et al. 1983); frequently isolated from soils (Nik Mohd Izham et al. 2005; Leslie \& Summerell 2006) and a pathogen to a large number of plant species, especially trees that show cankers and dieback symptoms (Nelson et al. 1983). However, no reports have been published in showing that $F$. solani is pathogenic to grasses.

Three species i.e. F. equiseti, F. compactum and F. longipes that belong to section Gibbosum were recovered particularly from the true grass samples. These species are cosmopolitan soil inhabitants that have been recovered from many parts of the world in cool and temperate to hot and arid regions, primarily as saprophytes or secondary invaders (Nelson et al. 1983; Summerell et al. 2003; Leslie \& Summerell 2006) and were also isolated from soils (Nelson et al. 1983; Leslie \& Summerell 2006). However, no report has shown these species are pathogenic to rice, sugarcane, and true grasses.

F. oxysporum is the most widely distributed and as an important vascular wilts pathogen on many plants, and a common soil saprophyte (Nelson et al. 1983; Leslie \& 
Summerell 2006). F. oxysporum has been reported as a serious pathogen on various plants but the species was avirulent to cereals and grasses despite that they are colonized by this species (Kommendahl et al. 1979; Leslie et al. 1990; Opperman \& Wehner 1994). Extensive surveys on ear blight of barley, wheat, maize, oats and rye in temperate areas showed no disease symptoms particularly vascular wilts disease even though F. oxysporum has been isolated from these crops (Bottalico \& Perrone 2002; Logrieco et al. 2002). This was also experienced in all of our grass samples (rice, sugarcane and true grasses) i.e. no symptoms of vascular wilts were observed during the study.

F. chlamydosporum is commonly found in soils and as a saprophyte or endophyte on a variety of substrates (Leslie \& Summerell 2006). This fungus is ubiquitous in arid and semi arid areas (Burgess \& Summerell 1992; Sangalang et al. 1995). The species is likely to colonize the plants as a secondary invader. F. chlamydosporum was believed to be nonpathogenic to the most plants as well as on rice, sugarcane, and true grasses (Salleh \& Strange 1988). Hence, the etiology of this species was rarely discussed by plant pathologists (Desjardins 2006; Leslie \& Summerell 2006).

Based on the Shannon-Weiner Index, F. solani $\left(\mathrm{H}^{\prime}=2.62\right)>F$. semitectum $\left(\mathrm{H}^{\prime}=2.45\right)>F$. equiseti $\left(\mathrm{H}^{\prime}=2.13\right)>F$. compactum $\left(\mathrm{H}^{\prime}=2.06\right)>F$. proliferatum $\left(\mathrm{H}^{\prime}=1.57\right)>F$. axysporum $\left(\mathrm{H}^{\prime}=1.13\right)>F$. subglutinans $\left(\mathrm{H}^{\prime}=1.12\right)>$ F. chlamydosporum $\left(\mathrm{H}^{\prime}=1.06\right)>F$. sacchari $\left(\mathrm{H}^{\prime}=0.65\right)>F$. longipes $\left(\mathrm{H}^{\prime}=0.00\right)>$ F. verticillioides $\left(\mathrm{H}^{\prime}=0.00\right)>$ F. fujikuroi $\left(\mathrm{H}^{\prime}=0.00\right)$. Therefore, the diversity of F. solani was the highest isolated and fairly common in the grasses Family than others Fusarium species.

There have been considerable assumptions about expected differences in fungal populations and species compositions between agricultural and non-agricultural ecosystems. The agricultural ecosystems are characterized by host populations that are relatively uniform genetically, numerically and patially (Burdon et al. 1989). As shown in Table 1, F. fujikuroi was the most prevalent species isolated $(14.6 \%)$ from O. sativa whereas $F$. sacchari was most frequently isolated $(12.2 \%)$ from the sugarcane $(S$. officinarum) planting areas. These data were in accordance with previous authors (Nirenberg \& O'Donnell 1998; Desjardins et al. 1997; Semangun 1991; Tan 1989). Meanwhile, a less uniform pattern of species distribution and dispersion could be observed in non-agricultural ecosystems as no specific Fusarium species colonized each of the grass samples.

\section{CONCLUSION}

As a conclusion, the occurrence of Fusarium species on agricultural and non agricultural grass samples in Peninsular Malaysia was considerably variable in terms of their diversity and distribution. 


\section{ACKNOWLEDGEMENT}

The authors gratefully thank to Mr. Azmi Abd Razak, Nik Mohd Izham Mohamed Nor and Mr. Kamaruddin Maidin for their tireless and help both in the laboratory and field works. Financial support was provided by the USM Research University Grants (1001/PBIOLOGY/811009).

\section{REFERENCES}

Al-Amodi M.O.S. 2006. Morphological, pathogenic, genetic and molecular variabilities of Fusarium sp., the pathogens of asparagus crown and root rot in Malaysia and Brunei Darussalam. PhD thesis. Universiti Sains Malaysia.

Booth C. 1971. The Genus Fusarium. Commonwealth Mycological Institute, Kew, Surrey. p. 221.

Bottalico A. and G. Perrone. 2002. Toxigenic Fusarium species and mycotoxins associated with head blight in small-grain cereals in Europe. European Journal of Plant Pathology, 108: 611-624.

Burdon J.J., Jarosz A.M. and G.C. Kirby. 1989. Pattern and patchiness in plant-pathogen interactions - causes and consequences. Annual Review of Ecology, Evolution, and Systematics, 20: 119 - 136.

Burgess L.W. and C.M. Liddell. 1983. Laboratory Manual for Fusarium Research. University of Sydney. p. 133.

Burgess L.W. and B.A. Summerell. 1992. Mycogeography of Fusarium: Survey of Fusarium species from subtropical and semi-arid grassland soils from Queensland, Australia. Mycological Research, 96: 780784.

Burgess L.W., Summerell B.A., Bullock S., Gott K.P. and D. Backhouse. 1994. Laboratory Manual for Fusarium Research. University of Sydney. p. 133.

Carter W.W. 1979. Corky dry rot of cantaloupe caused by Fusarium roseum 'Semitectum'. Plant Disease Reporter, 63: 1080-1084.

Chulze S.N., Ramirez M.L., Torres A. and J.F. Leslie. 2000. Genetic variation in Fusarium section Liseola from notill maize in Argentina. Applied and Environmental Microbiology, 65: 5312-5315.

Danielsen S., Meyer U.M. and D.F. Jensen. 1998. Genetics characteristics of Fusarium verticillioides isolates from maize in Costa Rica. Plant Pathology, 47: 615-622.

Desjardins A.E., Plattner R.D. and P.E Nelson. 1997. Production of fumonisin B $_{1}$ and moniliformin by Gibberella fujikuroi from rice from various geographic areas. Applied and Environmental Microbiology, 63: 18381842.

Desjardins A.E., Manandhar H.K., Plattner R.D., Maragos C.M., Shrestha K. and S.P McCormick. 2000. Occurrence of Fusarium species and mycotoxins in Nepalese maize and wheat and the effect of traditional processing methods on mycotoxin levels. Journal of Agricultural and Food Chemistry, 48: $1377-1383$.

Desjardins A.E. 2006. Fusarium mycotoxins: chemistry, genetics and biology. APS Press: St. Paul, MN, USA. p. 260.

Fisher N.L., Burgess L.W., Toussoun T.A. and P.E. Nelson. 1982. Carnation leaves as a substrate and for preserving cultures of Fusarium species. Phytopathology, 72:151-153.

Gilliland H.B., Holttum R. E. and N. L. Bor. 1971. A Revised Flora of Malay, Volume 3. Grasses of Malaysia. Government Printing Office, Singapore. p. 319.

Harada J., Shibayama H. and H. Morita. 1996. Weeds in Tropic. AICAF. Tokyo. Japan. p. 304.

Kedera C.J., Plattner R.D. and A.E. Desjardins. 1999. Incidence of Fusarium sp. and levels of fumonisin $\mathrm{B}_{1}$ in maize in western Kenya. Applied and Environmental Microbiology, 65: 31-44. 
Kim J.C., Lee Y.W. and S.H. Yu. 1995. Sambutoxin producing isolates of Fusarium species and occurrence of sambutoxin in rotten potato tubers. Applied and Environmental Microbiology, 61:3750-3751.

Klaasen J.A. and P.E. Nelson. 1998. Identity of Fusarium nygamai isolates with long and short microconidial chains from millet, sorghum and soil in Africa. Mycopathology, 140: 171-176.

Kommedahl T., Windels C.E. and R.E. Stucker. 1979. Occurrence of Fusarium species in roots and stalks of symptomless corn plants during the growing season. Phytopathology, 69: 961-966.

Kornerup A. and J.H. Wancher. 1978. Methuen Handbook of Colour. Eyre Methuen Ltd. p. 252.

Leslie J.F., Pearson C.A.S., Nelson P.E. and T.A. Toussoun. 1990. Fusarium species from corn, sorghum, and soybean fields in the central and eastern United States. Phytopathology, 80: 343-350.

Leslie J.F. 1995. Gibberella fujikuroi: Available populations and variable trait. Canadian Journal of Botany, 73: 282291.

Leslie J.F. and B.A. Summerell. 2006. The Fusarium Laboratory Manual. Blackwell Publishing Ltd, UK. p.388.

Leslie J.F., Zeller K.A. and B.A. Summerell. 2001. Icebergs and species in populations of Fusarium. Physiology Molecular Plant Pathology, 59: 107-117.

Logrieco A., Mullè G., Moretti A. and A. Bottalico. 2002. Toxigenic Fusarium species and mycotoxins associated with maize ear rot in Europe. European Journal of Plant Pathology, 108: 597-600.

Mulè G., Susca A., Stea G. and A. Moretti. 2004. A species-specific PCR assay based on calmodulin partial gene for identification of Fusarium verticillioides, F. proliferatum and F. subglutinans. European Journal of Plant Pathology, 110: 495-502.

Munkvold G.P. and A.E. Desjardins. 1997. Fumonisins in maize: Can we reduce their occurrence? Plant Disease, 81:556-565.

Nelson P.E., Toussoun T.A. and W.F.O. Marasas. 1983. Fusarium species: An Ilustrated Manual for Identification. The Pennsylvania State University Press. p. 193.

Nik Mohd Izham, M.N., Nor Azliza, I., Nur Ain Izzati, M.Z., Azm, A.R., Siti Nordahliawate, M.S. and B. Salleh. 2005. Diversity of Fusarium species in the Soils of Penang Island. In: $27^{\text {th }}$ Symposium of the Malaysian Society for Microbiology, 24 - 27 November 2005, Grand Plaza Parkroyal, Penang.

Nirenberg H. I. and K. O'Donnell. 1998. New Fusarium species and combinations within the Gibberella fujikuroi species complex. Mycologia, 90: 434-458.

Nor Azliza I., Nik Mohd Izham M.N., Nur Ain Izzati M.Z., Azmi A.R., Siti Nordahliawate M.S. and B Salleh. 2005. A preliminary report on the diversity of Fusarium spp. on grasses in the Malaysian Peninsula. In: $27^{\text {th }}$ Symposium of the Malaysian Society for Microbiology, 24 - 27 November 2005, Grand Plaza Parkroyal, Penang.

Nur Ain Izzati M. Z., Azmi A.R. and B. Salleh. 2008. Bakanae disease of rice in Malaysia and Indonesia: Etiology of the causal agent based on morphological, physiological and pathogenicity characteristics. Journal of Plant Protection Research, 48: 491-501.

Opperman L. and F.C. Wehner. 1994. Survey of fungi associated with grass roots in virgin soils on the Springbok Flats. South African Journal of Botany, 60: 67-72.

Salleh B. and B. Sulaiman. 1984. Fusaria associated with naturally diseased plants in Penang. Journal of Plant Protection in the Tropics, 1: 47-53.

Salleh B. and R.N. Strange. 1988. Toxigenicity of some Fusaria associated with plant and human diseases in the Malaysian Peninsula, Malaysia. Journal of General Microbiology, 134: 841-848.

Sangalang A.E., Backhouse D. and L.W. Burgess. 1995. Survival and growth in culture of four Fusarium species in relation to occurrence in soils from hot climatic regions. Mycological Research, 99: 529-533.

Satou M., Ichinoe F., Fukumoto N., Tezuka and S. Horiuchi. 2001. Fusarium blight of kangaroo pow (Anigozanthos spp.) caused by Fusarium chlamydosporum and F. semitectum. Journal of Phytopathology, 149: 203-206.

Semangun H. 1991. Host index of plant disease in Indonesia. Jogjakarta: Gadjah Mada University Press. p. 850. 
Siti Nordahliawate M.S., Nur Ain Izzati M.Z., Azmi A.R. and B. Salleh. 2008. Distribution, Morphological Characterization and Pathogenicity of Fusarium sacchari Associated with Pokkah Boeng Disease of Sugarcane in Peninsular Malaysia. Journal of Tropical Agriculture and Food Science, 31: 279-286.

Spellerberg I.F. 2008. Encyclopedia of Ecology. Lincoln University, Lincoln, New Zealand. 3249-3252.

Summerell B.A., Salleh B. and J.F. Leslie. 2003. A utilitarian approach to Fusarium identification. Plant Disease, 87: 117-128.

Tan S.L. 1989. Sugarcane Production in Peninsular Malaysian. Malaysian Agricultural Research and Development Institute. p. 97-99.

Wan Hassan W.E. 1999. Pengenalan Dalam Foraj Untuk Ternakan. Institut Penyelidikan dan Kemajuan Malaysia (MARDI) Kuala Lumpur. 1-4.

Webster R.K. and P.S. Gunnell. 1992. Compendium of Rice Diseases. The American Phytopathological Society Press, St. Paul, Minn. p. 27.

Wycherley P.R. and A.A. Yusof. 1974. Grasses in Malaysian Plantation. Rubber Research Institute of Malaysia. p. 176. 